\title{
FOOT SELF-CARE PADA PENYANDANG DIABETES MELLITUS (DM): PILOT STUDY DI SEMARANG
}

\author{
Ainur Muhti Ashari' ${ }^{1)}$, Niken Safitri Dyan Kusumaningrum²) \\ ${ }^{1}$ Mahasiswa Program Studi Ilmu Keperawatan Departemen Ilmu Keperawatan, FK Universitas Diponegoro email: \\ ainur.muhti@gmail.com \\ ${ }^{2}$ Dosen Keperawatan Medikal Bedah, Departemen Ilmu Keperawatan FK Universitas Diponegoro email: \\ niken.safitridk@fk.undip.ac.id
}

\begin{abstract}
Diabetes Mellitus (DM) is a chronic metabolic disease that has the characteristic of hyperglycemia as a result of insulin insufficiency. It lead to common lower extremity complication, called diabetic foot ulcers (DFU). This complication should be prevented by performing an adequate foot self-care. Unfortunately, patients' with DM awareness on foot self-care are still need to be improved. This study aimed to identify how foot self-care were applied in patients with DM. This was a cross-sectional study using Diabetic Foot Self-care Questionnaire University of Malaga that was distributed to respondents. Respondents met the inclusion criteria was consecutively recruited to the study. Data was univariately analyzed then resulted frequency and percentage distribution. A number of 112 patients with DM had participated in this study. Respondents who participated in this study were age 41-60 years (69,6\%), female $(78,6 \%)$, no education in foot self-care (50\%), and suffering from DM for less than 10 years $(80,4 \%)$. It is showed that $52.7 \%$ of patients with DM have adequate foot self-care. This category was grouped based on 3 aspects entitled personal self-care, podiatric care, also footwear and socks. Each of these aspects include several activities as a part of foot self-care. In conclusion, more patients with $D M$ are categorized as appropriate foot self-care than inappropriate foot self-care. Therefore, it is needed to give more information to patients with diabetes in order to apply proper foot self-care especially the examination of the feet, using lotion, socks, and the way to get the feet warm.
\end{abstract}

Keywords: Diabetes mellitus, diabetic foot ulcer, foot care, foot self-care

\section{PENDAHULUAN}

Diabetes Mellitus (DM) adalah penyakit kronis metabolik dengan karakteristik hyperglikemia karena adanya defisiensi insulin dan menimbulkan gangguan multisistem (Odhayani, Tayel and Al-madi, 2016). Di Indonesia, jumlah penyandang DM pada tahun 2017 adalah 10,3 juta dan akan meningkat di tahun 2045 menjadi 16,7 juta (Aprilyasari, 2015; Cho et al., 2017, 2018).

Penyakit DM yang tidak mendapatkan perawatan dengan baik akan menimbulkan munculnya komplikasi, salah satunya adalah ulkus kaki diabetik. Menurut World Health Organization (WHO) ulkus kaki diabetik adalah perlukaan yang muncul pada kaki penyandang DM yang memiliki potensi resiko terjadinya konsekuensi patologis, termasuk infeksi, ulserasi, dan rusaknya jaringan yang berhubungan dengan kelainan neurologi, penyakit vaskuler, dan komplikasi metabolik (Chand et al., 2012). Diperkirakan 15-25\% dari orang dewasa dengan DM tipe 2 mengalami ulkus pada kaki sepanjang hidupnya dan sebanyak $70 \%$ mengalami amputasi non-traumatik disebabkan oleh komplikasi DM. Amputasi dapat menyebabkan efek kerugian yang besar dilihat dari segi finansial, keterbatasan fisik, penurunan kualitas hidup, dan bahkan tingginya tingkat kematian (Sheila et al., 2016).

Ulkus kaki diabetik dapat diatasi dengan foot self-care yang tepat, meliputi aspek personal self-care, podiatric care, dan footwear and sock. Foot self-care merupakan salah satu intervensi keperawatan yang bersifat preventif dalam bentuk kegiatan membersihkan dan menginspeksi daerah kaki, mengeringkan dan memberi minyak pada kaki yang bertujuan untuk relaksasi, kebersihan, dan kesehatan kulit (Bulechek et al., 2013; Smeltzer and Bare, 2013). Penelitian sebelumnya menunjukkan bahwa pelaksanaan 
foot self-care secara signifikan dapat mencegah dan mengurangi keparahan ulkus kaki diabetik yang dialami penyandang DM. Penerapan foot self-care yang dilakukan selama 2 tahun pada kelompok yang beresiko, didapatkan hasil dari 88 penyandang DM terjadi peningkatan kesembuhan kalus dari $64 \%$ menjadi $72 \%$ penyandang DM dan peningkatan penyembuhan kejadian tinea pedis dari 14\% menjadi 38\% penyandang DM (Funahashi, Shimomura and Shimizu, 2011).

Penelitian oleh Sheila, et. al. di Oman menyatakan bahwa dari 160 penyandang DM sekitar $15,7 \%$ partisipan memiliki riwayat ulkus pada kaki, serta $41,4 \%$ merasa kesemutan dan nyeri pada kaki (Sheila et al., 2016). Mayoritas partisipan $(87,8 \%)$ mencuci kakinya setiap hari, dan $53,5 \%$ berjalan tanpa alas kaki. Dari data di atas dapat diartikan bahwa perawatan kaki pada klien dirasa kurang optimal karena masih minimnya perilaku penggunaan alas kaki yang dapat meningkatkan resiko terjadinya luka yang tidak disadari oleh penyandang DM (Sheila $e t$ al., 2016).

Selain itu, penelitian sebelumnya oleh Li et. al. di Cina juga menunjukkan bahwa perawatan kaki yang dilakukan oleh penyandang DM dikatakan masih cenderung rendah. Sebanyak 70,90\% dari 5961 penyandang DM memiliki tingkat pengetahuan yang baik, namun hanya $41 \%$ yang menerapkan perawatan kaki secara mandiri (Li et al., 2014).

Penelitian mengenai penerapan foot selfcare di Indonesia masih cenderung terbatas. Melihat berbagai fenomena yang diuraikan sebelumnya, peneliti merasa perlu melihat bagaimana foot self-care dilakukan oleh penyandang DM. Penelitian pilot study ini bertujuan untuk mengidentifikasi bagaimana pelaksanaan foot self-care yang dilakukan oleh penyandang DM.

\section{METODE}

Penelitian ini merupakan jenis penelitian kuantitatif dengan pendekatan cross-sectional. Teknik pengambilan sampel yang digunakan adalah consecutive sampling. Kriteria inklusi untuk responden adalah penyandang DM dengan usia > 18 tahun. Data diambil menggunakan kuesioner Diabetic Foot SelfCare Questionnaire University of Malaga versi bahasa Indonesia dengan nilai validitas $r$ hitung 0,419-0,653 dan nilai reliabilitas 0,6.

Data dianalisis secara univariat yang menghasilkan tabel distribusi frekuensi dan persentase. Penelitian ini telah disetujui oleh Komisi Etik Penelitian Fakultas Kedokteran Universitas Diponegoro dengan No. 346/EC/FK-RSDK/V/2018.

\section{HASIL DAN PEMBAHASAN}

Sebanyak 112 responden dengan DM berpartisipasi dalam penelitian ini. Hasil penelitian menunjukkan bahwa mayoritas penyandang DM berjenis kelamin perempuan $(78,6 \%)$ dan menderita DM $<10$ tahun $(80,4 \%)$.

Selain itu, jika dilihat dari pengalaman mendapatkan edukasi tentang foot self-care, baik penyandang DM yang sudah maupun yang belum mendapatkan edukasi tentang perawatan kaki, mempunyai prosentase yang sama (50\%). Distribusi frekuensi karakteristik demografi responden disampaikan pada tabel 1.

Tabel 1 Distribusi Frekuensi Karakteristik Demografi Responden di Puskesmas Rowosari Semarang $(\mathbf{N}=112)$

$\begin{array}{ccc}\text { Kategori Responden } & \text { Frekuensi } & \begin{array}{c}\text { Persentase } \\ (\%)\end{array}\end{array}$




\begin{tabular}{|c|c|c|}
\hline \multicolumn{3}{|l|}{ Usia } \\
\hline Dewasa awal & 2 & 1,8 \\
\hline Dewasa tengah & 78 & 69,6 \\
\hline Dewasa akhir & 32 & 28,6 \\
\hline \multicolumn{3}{|l|}{ Jenis Kelamin } \\
\hline Laki-laki & 24 & 21,4 \\
\hline Perempuan & 88 & 78,6 \\
\hline \multicolumn{3}{|l|}{ Lama Menderita } \\
\hline$<10$ & 90 & 80,4 \\
\hline$\geq 10$ & 22 & 19,6 \\
\hline \multicolumn{3}{|l|}{ Tingkat pendidikan } \\
\hline Tidak sekolah & 55 & 49,1 \\
\hline SD & 35 & 31,3 \\
\hline SMP & 7 & 6,3 \\
\hline SMA & 8 & 7,1 \\
\hline Perguruan Tinggi & 7 & 6,3 \\
\hline \multicolumn{3}{|l|}{$\begin{array}{l}\text { Pengalaman } \\
\text { mendapatkan } \\
\text { edukasi }\end{array}$} \\
\hline \multicolumn{3}{|l|}{$\mathrm{Ya}$} \\
\hline Tidak & 56 & 50 \\
\hline & \multicolumn{2}{|c|}{ diabetik } \\
\hline \multicolumn{3}{|l|}{$\mathrm{Ya}$} \\
\hline \multirow[t]{2}{*}{ Tidak } & 25 & 22,3 \\
\hline & 87 & 77,7 \\
\hline
\end{tabular}

Tabel 2 Distribusi Frekuensi Tingkat Foot Self-Care di Puskesmas Rowosari Semarang (N=112)

\begin{tabular}{ccc}
\hline Tingkat Foot Self Care & Frekuensi & Persentase (\%) \\
\hline Baik & 59 & 52,7 \\
Buruk & 53 & 47,3 \\
\hline Total & 112 & 100
\end{tabular}

Selain itu, tabel 2 menunjukkan bahwa lebih banyak penyandang DM termasuk dalam kategori baik pada tingkat foot self-care yaitu sebanyak $59(52,7 \%)$ daripada yang buruk. Pengkategorian foot self-care ini merupakan kesimpulan dari ketiga aspek yang dinilai, yang meliputi aspek personal self-care, podiatric care, dan foot wear \& socks.

Sebesar $29,5 \%$ dari responden penyandang DM teridentifikasi tidak pernah memeriksa kakinya. Selain itu, 88,4\% dari responden penyandang DM tersebut mencuci kakinya dua kali sehari. Namun, sayangnya lebih banyak penyandang DM $(59,8 \%)$ yang tidak melakukan tindakan apapun setelah mengeringkan kakinya.

Dilihat dari sisi penerimaan informasi mengenai foot self-care, sebanyak 39,3\% dari responden penyandang DM termasuk dalam kategori "sangat tidak adekuat" yaitu tidak menerima informasi dan tidak tahu cara merawat kaki. Namun demikian, mereka telah melakukan perawatan terhadap kulit kasar dan menebal, di mana sebagian besar penyandang DM $(64,3 \%)$ masuk dalam kategori "sangat adekuat" dengan memilih pergi ke pelayanan kesehatan untuk mengatasi masalah tersebut.

Pada aspek footwear and socks penelitian menunjukkan bahwa masih banyak penyandang DM $(60,7 \%)$ yang belum menggunakan kaos kaki untuk melindungi kakinya. Selain itu, mereka $(64,3 \%)$ juga masih kurang peduli dan tidak memahami apa pentingnya menghangatkan kaki. Namun demikian, $45.5 \%$ dari responden penyandang DM telah memilih alas kaki dengan baik. Mereka telah menggunakan sepatu atau sandal dengan ujung pas, tidak sempit, dan tidak longgar dengan insole lembut, dan sirkulasi baik.

Aspek personal self-care 
Aspek ini mencakup bentuk perawatan kaki yang harus dilakukan oleh penyandang DM setiap hari untuk mencegah terjadinya ulkus kaki. Pemeriksaan kaki harus dilakukan setiap hari untuk memeriksa apakah terdapat gejala kemerahan, lepuh, fisura, kalus atau ulserasi. (Hidayat and Nurhayati, 2014). Pada penelitian ini lebih banyak penyandang DM yang tidak pernah memeriksa kakinya. Penelitian lain juga menyatakan bahwa sekitar $30.8 \%$ penyandang DM tidak pernah melakukan pemeriksaan keadaan kaki (Hanif and Kusumaningrum, 2015). Banyak penyandang DM beranggapan bahwa pemeriksaan kaki hanya perlu dilakukan saat dirinya telah memiliki luka pada kaki.

Untuk membersihkan diri, mencuci kaki sebaiknya dilakukan minimal 1 kali per hari selama \pm 3 menit. Penggunaan sabun yang lembut sangat direkomendasikan untuk menghindari cedera. Selain itu, air yang direkomendasikan adalah air biasa. Hal ini dikarenakan penyandang DM sangat beresiko mengalami neuropati yang akan menurunkan sensasi pada kaki (Embil et al., 2018). Keteraturan penyandang DM dalam melakukan mencuci kaki menunjukkan hasil yang baik. Hal ini diperinci dengan keadekuatan penyandang DM dalam memilih air untuk mencuci kaki dan menggunakan air biasa untuk mencuci kaki.

Bentuk aspek personal care selanjutnya adalah mengeringkan kaki. Mengeringkan kaki yang disarankan adalah menggunakan handuk yang lembut, dan berwarna cerah. Bagian yang memerlukan perhatian lebih adalah sela-sela jari kaki. Keadekuatan penyandang DM dalam mengeringkan kaki dapat dipengaruhi oleh anggapan penyandang DM bahwa kakinya akan kering dengan sendirinya dan tidak perlu untuk dikeringkan. Kondisi kaki penyandang DM yang dibiarkan dalam keadaan basah akan meningkatkan kelembapan yang rentan terkena infeksi jamur (Smeltzer and Bare, 2013). Masih banyak penyandang DM yang tidak melakukan tindakan apapun agar kakinya segera kering.

Untuk menjaga kelembaban kulit, hasil penelitian ini identik dengan hasil penelitian sebelumnya yang menyatakan bahwa sebagian besar penyandang DM $(92,5 \%)$ tidak menggunakan krim pelembab pada kaki mereka (Dikeukwu and Omole, 2013). Hal ini disebabkan penyandang DM pada rentang usia dewasa akhir cenderung menganggap penggunaan krim pelembab bukanlah hal yang wajar untuk digunakan. Padahal penggunaan krim pelembab tersebut bermanfaat untuk menghindari kulit kering (Hidayat and Nurhayati, 2014). Penggunaan pelembab merupakan salah satu tindakan yang dilakukan untuk menjaga moisture balance (kelembaban kulit). Namun, yang paling penting adalah tetap memperhatikan bahwa topical yang digunakan untuk menjaga kelambaban kulit tersebut harus sesuai dengan $\mathrm{pH}$ kulit, sehingga tidak menyebabkan iritasi atau pun kerusakan kulit lainnya.

Pemeriksaan kuku dan memotong kuku secara rutin merupakan upaya selanjutnya dalam mencegah ulkus kaki diabetik. Pemeriksaan yang tepat meliputi inspeksi ada tidaknya ingrown nail, robekan, dan retakan pada kuku. Selain itu, memotong kuku menggunakan alat khusus pemotong kuku kaki. Posisi pemotongan lurus mengikuti bentuk normal jari kaki, dan tidak terlalu pendek. Pemeriksaan dan pemotongan kuku kaki ini minimal dilakukan satu minggu sekali (Odhayani, Tayel and Al-madi, 2016).

Sudah lebih banyak penyandang DM yang melakukan pemeriksaan kuku kaki secara adekuat. Mereka telah memeriksa kukunya setiap seminggu sekali. Sudah lebih banyak dari para penyandang DM ini juga telah memotong kukunya menggunakan gunting kuku dan memotong sesuai bentuk kuku. Cara memotong kuku yang kurang baik ini dapat menyebabkan kuku ke dalam, luka pada jari, dan meningkatkan risiko terjadinya ulkus kaki diabetik (Cavanagh et al., 2005).

\section{Aspek podiatric care}

Aspek ini menggambarkan kesulitan dan kendala yang dialami penyandang DM dalam melakukan perawatan kaki. Persepsi penyandang DM terhadap pentingnya melakukan foot self-care secara rutin sangat baik. Hal tersebut dibuktikan dengan persentase yang sama oleh penyandang DM yang menjawab sangat penting dan penting tentang urgensi foot self-care ini. Namun di sisi lain masih cukup banyak pula penyandang DM yang tidak mendapatkan informasi dan tidak tahu cara merawat kaki. Maka dari itu edukasi tentang perawatan kaki masih perlu 
untuk diberikan agar penyandang DM paham, dan dapat melaksanakan perawatan dengan baik, dan teratur serta, sebagai media penyandang DM untuk mendapatkan motivasi, dan dukungan emosinal (Li et al., 2014).

Hal pertama yang dilakukan saat timbul kulit kaki yang kasar atau kalus adalah konsultasi ke podiatrist. Bila podiatrist merekomendasikan untuk melakukan perawatan mandiri maka penyandang DM dapat menghaluskan kalus dan corn dengan menggunakan alat khusus setelah mandi. Sebagian besar penyandang DM juga telah melaporkan bahwa mereka memilih untuk pergi ke pelayanan kesehatan untuk melakukan perawatan kulit. Hal tersebut menunjukkan bahwa sebagian besar penyandang DM memiliki kesadaran yang baik untuk mendapatkan skrining masalah kaki dan mendapatkan penanganan foot-care oleh perawat profesional atau podiatrist di pelayanan kesehatan (Funahashi, Shimomura and Shimizu, 2011). Selain itu, penggunaan terapi antimikrobial dapat diberikan untuk menangani infeksi bila terjadi perlukaan (Cavanagh et al., 2005).

\section{Aspek footwear and socks}

Aspek footwear and socks meliputi cara pemilihan alas kaki dan kaos kaki yang digunakan. Pemilihan alas kaki yang tepat harus memperhatikan ujung yang tidak sempit dengan insole yang lembut dan sirkulasi udara yang baik. Insole yang lembut akan memperkecil tekanan pada kaki (Smeltzer and Bare, 2013). Pemilihan alas kaki adalah salah satu tindakan yang perlu diperhatikan. Penyandang DM harus menggunakan sepatu atau sandal dengan ujung yang pas, sesuai dengan bentuk kaki mereka, ukuran tidak terlalu ketat, dan insole yang lembut. Saat hendak menggunakan alas kaki, penyandang DM juga harus memeriksa bagian dalam alas kaki sebelum digunakan bertujuan untuk mencegah adanya benda asing yang dapat melukai kaki, atau binatang yang menyengat (Dikeukwu and Omole, 2013).

Penggunaan kaos kaki yang direkomendasikan adalah dari bahan yang menyerap keringat, dan menghangatkan kaki seperti katun. Pemilihan kaos kaki tidak boleh terlalu kecil, dan ketat karena dikhawatirkan akan menghambat peredaran darah ke ekstermitas bawah (Hidayat and Nurhayati, 2014). Kaos kaki merupakan salah satu sarana yang mudah digunakan untuk mencegah terjadinya dam[ak neuropati pada kaki juga dapat mengakibatkan penurunan sensitivitas terhadap suhu yang panas maupun dingin (Smeltzer and Bare, 2013).

\section{KESIMPULAN}

Lebih banyak penyandang DM masuk dalam kategori baik pada tingkat foot self-care. Bagi Puskesmas, perlu adanya peningkatan edukasi bagi penyandang DM tentang foot selfcare terutama tentang pemeriksaan kaki, penggunaan pelembab, dan kaos kaki, serta cara menghangatkan kaki. Peneliti lain diharapkan melakukan penelitian lanjutan mengenai keefektifan foot self-care untuk mencegah terjadinya ulkus kaki dengan metode kuesioner dan observasi.

\section{UCAPAN TERIMA KASIH}

Terima kasih peneliti sampaikan kepada Puskemas Rowosari Semarang yang telah memberikan ijin penelitian dan para penyandang DM yang telah bersedia menjadi subjek penelitian ini.

\section{REFERENSI}

Aprilyasari, R. W. (2015) 'Hubungan lama menderita DM dengan perilaku perawatan kaki secara mandiri untuk mencegah ulkus diabetikum', Jurnal Keperawatan dan Kesehatan Masyarakat, 2(3), pp. 29-35.

Bulechek, G. M. et al. (2013) Nursing interventions classification (NIC). 6th edn. United Stated of America: Elsevier Ltd.

Cavanagh, P. R. et al. (2005) 'Treatment for diabetic foot ulcers', 366, pp. 1725-1735.

Chand, G. et al. (2012) 'Clinical queries: nephrology diabetic foot', Clinical Queries Nephrology. Reed Elsevier India Pvt. Ltd, $1(2)$, pp. 144-150. doi: 10.1016/S22119477(12)70009-2.

Cho, N. H. et al. (2017) IDF Diabetes Atlas. Eight edit, IDF Diabetes Atlas, 8th edition. Eight edit. doi: http://dx.doi. org/10.1016/S0140-6736(16)31679-8. 
Cho, N. H. et al. (2018) 'IDF Diabetes Atlas: Global estimates of diabetes prevalence for 2017 and projections for 2045', Diabetes Research and Clinical Practice. Elsevier B.V., 138, pp. 271-281. doi: 10.1016/j.diabres.2018.02.023.

Dewi, N. K. (2017) 'Hubungan antara foot self-care dan neuropati perifer pada diabetisi', skripsi, p. 77.

Dikeukwu, R. and Omole, O. (2013) 'Awareness and practices of foot self-care in patients with diabetes at Dr Yusuf Dadoo District Hospital, Johannesburg', Journal of Endocrinology, Metabolism and Diabetes of South Africa, 18(2), pp. 112-118. doi: 10.1080/22201009.2013.10872314.

Embil, J. M. et al. (2018) 'Foot Care', Canadian Journal of Diabetes. Elsevier Inc., 42, pp. 222-227. doi: 10.1016/j.jcjd.2017.10.020.

Funahashi, T., Shimomura, I. and Shimizu, Y. (2011) 'Beneficial effects of foot care nursing for people with diabetes mellitus: An uncontrolled before and after intervention study', Journal of Advanced Nursing, 9, pp. 1952-1962. doi: 10.1111/j.13652648.2011.05640.x.

Hanif, E. A. and Kusumaningrum, N. S. D. (2015) Foot self-care pada pasien dengan diabetes melitus di RSUD Kraton Pekalongan, skripsi. Universitas Diponegoro. Available at: http://eprints.undip.ac.id/49442/.

Hidayat, R. A. and Nurhayati, I. (2014) 'Perawatan kaki pada penderita diabetes militus di rumah', Jurnal Permata Indonesia, 5(2), pp. 49-54.

Li, R. et al. (2014) 'The current status of foot self-care knowledge, behaviours, and analysis of influencing factors in patients with type 2 diabetes mellitus in China', International Journal of Nursing Sciences, 1(3), pp. 266271. doi: 10.1016/j.ijnss.2014.05.023.

Navarro-Flores, E. et al. (2014) 'Development, validation and psychometric analysis of the diabetic foot self-care questionnaire of the University of Malaga, Spain (DFSQ-UMA).', Journal of tissue viability. doi: 10.1016/j.jtv.2014.11.001.

Odhayani, A., Tayel, S. and Al-madi, F. (2016) 'Foot care practices of diabetic patients in Saudi Arabia', Saudi Journal of Biological Sciences. King Saud University, 24(7), pp. 1667-1671. doi: 10.1016/j.sjbs.2015.12.003.

Sheila, M. et al. (2016) 'Foot care behaviors among adults with Type 2 diabetes', Primary Care Diabetes. Primary Care Diabetes Europe, 6(10), pp. 442-451. doi: 10.1016/j.pcd.2016.04.002.

Smeltzer, S. C. and Bare, B. G. (2013) Buku ajar keperawatan medikal bedah Brunner \& Suddarth. 8th edn. Jakarta: EGC. 